\title{
PERANAN AGAMA DALAM PEMBANGUNAN KABUPATEN SAMOSIR
}

\author{
Gontí Simanullang*
}

\begin{abstract}
Abstrak
Agama pasti memberi peranan signifikan dalam pembangunan manusia, sebab agama-agama mengajarkan kepada para penganutnya hal-hal yang secara moral baik dan benar. Bahwa beberapa penganut agama belum berperilaku sesuai dengan ajaran agamanya, sebagaimana terdapat dalam Statistik Kabupaten Samosir, tidaklah dengan sendirinya meniadakan atau menyangkal peranan agama dalam pembangunan masyarakat. Sarasehan tentang "Peranan Agama dalam Pembangunan Kabupaten Samosir" yang diorganisir oleh Pemerintah Kabupaten Samosir dan dihadiri oleh tokoh-tokoh agama dan masyarakat bertujuan untuk mendongkrak relevansi dan kontribusi agama, khusunya para penganut agama, dalam meningkatkan kehidupan bermasyarakat yang lebih baik, adil, jujur dan damai. Untuk tujuan itu, salah satu peranan signifikan agama yang dielaborasi dalam tulisan ini adalah edukasi moral. Karena mayoritas besar penganut agama yang terdapat di Kabupaten Samosir adalah Kristen, maka edukasi moral itu didekati dari sudut kekristenan. Edukasi moral itu terkadung dalam Alkitab, khususnya dalam dekalog atau Sepuluh Perintah Allah. Tiga abad sebelum kekristenan, landasan moral ini telah digariskan oleh Aristoteles.
\end{abstract}

Kata-kata kunci: agama, moral, dekalog, kristiani, kabupaten, penganut.

\section{Pendahuluan}

Saya mengucapkan terima kasih yang tulus kepada Pemerintah Kabupaten Samosir atas undangan dan kepercayaan yang diberikan kepada saya untuk berbicara pada sarasehan dengan para tokoh agama dan para tokoh masyarakat se-Kabupaten Samosir yang berlangsung hari ini, Rabu, 25 Juni 2014, di Hotel Dainang, Panguruan. Saya mengucapkan selamat datang kepada para tokoh agama dan para tokoh masyarakat yang bergegas meninggalkan pekerjaan untuk bisa menghadiri sarasehan ini.

Topik yang saya elaborasi adalah Peranan Agama dalam Pembangunan Kabupaten Samosir. Topik ini langsung mengingatkan 
saya pada debat antara Tony Blair - mantan Perdana Menteri Inggris (1997-2007), yang pindah dari Anglikan ke Katolik - dan Christoper Hitchens - keturunan Amerika-Inggris, penulis, jurnalis dan ateis - yang berlangsung di Toronto, Kanada, tentang whether or not religion is a force for good in the world. Tony Blair memosisikan dirinya pro dan Christoper Hitchens kontra. Dalam kaitan dengan topik Peranan Agama dalam Pembangunan Kabupaten Samosir, posisi saya adalah pro, yakni agama memiliki peranan dalam pembangunan Kabupaten Samosir.

\section{Observasi}

Observasi di bawah ini, di satu sisi membanggakan, di sisi lain memprihatinkan. Mari kita teropong sisi yang membanggakan. Negara Kesatuan Republik Indonesia (NKRI) dikenal sebagai negara beragama yang berketuhanan Yang Maha Esa. Kita bangga bahwa NKRI dihuni oleh masyarakat yang beriman dan takwa. Buktinya? Pada hari-hari besar umat beragama tertentu, rumah-rumah ibadat penuh sesak oleh kaum beriman. Umat Kristen pun makin terbiasa dengan perayaan paskah dan natal oikumene dengan tema yang mulia dan luhur, baik pada tingkat kota dan kabupaten maupun propinsi dan nasional. Saat pelantikan, para pemegang pemerintahan dengan penampilan yang elegan dan aromatik disumpah di atas Kitab Suci sesuai dengan agama dan kepercayaan orang bersangkutan. Lagu kebangsaan Indonesia Raya dan Padamu Negeri dinyanyikan dengan posisi tubuh berdiri tegak dan meyakinkan. Abdi-abdi negara kita itu pun bersumpah dengan lantang. Bagi saya kenyataan ini benar-benar membanggakan.

Sekarang mari kita tilik sisi yang memprihatinkan. Dalam kehidupan riil, kita bisa (sangat) kasar, liar, kejam, tak bersahabat dan saling mendahului. Walaupun di antara kita masih ada orang yang berani berkata kepada para pemungut cukai: "Jangan menagih lebih dari pada apa yang ditentukan bagimu," dan kepada prajurit-prajurit, "Jangan merampas dan jangan memeras dan cukupkanlah dirimu dengan gajimu," namun dalam realita penyelewengan, pemerasan, dan perampasan bukanlah peristiwa yang jarang terjadi. Siapa lagi yang berani berkata ia harus makin besar, tetapi aku harus makin kecil? Tidakkah setiap orang berlomba menjadi besar dan karena itu terjadilah hal-hal yang mencerminkan bahwa kita lain di bibir lain di hati, lain kini, lain nanti? Kita tampak saleh dan taat beragama, namun dalam interaksi antar kita bisa kasar, liar, arogan, dan kejam bila tidak sadis. 
Gonti Simanullang, Peranan Agama dalam Pembangunan Kabupaten Samosir

\section{Realita Kabupaten Samosir}

Yang dimaksud dengan realita Kabupaten Samosir di sini adalah hal-hal yang berkaitan dengan topik presentasi ini yakni jumlah rumah ibadat, jumlah penganut agama atau kepercayaan dan persentasenya, serta jumlah narapidana, kejahatan dan pelanggaran. Sumber rujukan adalah Badan Pusat Statistik Kabupaten Samosir dalam bentuk Portable Document Format (PDF) yang dikeluarkan tahun 2009 dengan judul SAMOSIR DALAM ANGKA.

Pada tahun 2009, empat tahun sesudah pembentukan Kabupaten Samosir, Badan Pusat Statistik Kabupaten Samosir mempublikasikan apa yang disebut dengan SAMOSIR DALAM ANGKA. Sebagai seorang peneliti, saya mengapresiasi publikasi itu: tebalnya 495 halaman, datanya lengkap dan mendetail selama periode 5 tahun yakni dari tahun 2004 sd 2008, formatnya apik, dan dwilingual (Indonesia dan Inggris). Tiga data yang menarik perhatian saya dari publikasi SAMOSIR DALAM ANGKA itu adalah: (1) jumlah rumah ibadat, (2) jumlah penganut agama atau kepercayaan dan persentasenya, dan (3) banyaknya narapidana dan tahanan pada Cabang Rumah Tahanan Negara di Pangururan.

1. Jumlah Rumah Ibadah di Kabupaten Samosir

\begin{tabular}{|c|c|c|c|c|}
\hline \multirow{2}{*}{ TAHUN } & \multicolumn{2}{|c|}{ GEREJA } & \multirow{2}{*}{ MESJID } & \multirow{2}{*}{ JUMLAH } \\
\hline & KRISTEN & KATOLIK & & \\
\hline A & B & $\mathrm{C}$ & D & $E$ \\
\hline 2008 & 290 & 134 & 7 & 431 \\
\hline 2007 & 288 & 133 & 7 & 428 \\
\hline 2006 & 256 & 132 & 7 & 395 \\
\hline 2005 & 256 & 132 & 6 & 394 \\
\hline 2004 & 211 & 132 & 6 & 349 \\
\hline
\end{tabular}

Data ini mengatakan bahwa dalam 5 tahun pertambahan rumah ibadat adalah: 79 gereja Kristen, 2 gereja Katolik, dan 1 mesjid. Rumah ibadat Kristen dan Katolik pada tahun 2008 terdapat sebanyak 424. 
2. Jumlah Penganut Agama dan Persentase

Jumlah penganut agama dan persentasenya adalah sebagai berikut: Kristen 68,576 jiwa (56,85\%), Katolik 50.249 (41,66\%), Muslim 1.205 $(1,00 \%)$, dan lainnya $588(0,49 \%)$. Data ini mengatakan bahwa jumlah penganut agama Kristen dan Katolik ada sebanyak 118.825 jiwa $(98,51 \%)$.

3. Banyaknya Narapidana dan Tahanan pada Cabang Rumah Tahanan Negara di Pangururan menurut Jenis Kejahatan dan Pelanggaran

\begin{tabular}{|c|c|c|c|c|c||}
\hline Jenis Kejahatan & $\mathbf{2 0 0 4}$ & $\mathbf{2 0 0 5}$ & $\mathbf{2 0 0 6}$ & $\mathbf{2 0 0 7}$ & $\mathbf{2 0 0 8}$ \\
\hline A & B & C & D & E & F \\
\hline Pembakaran & & & 4 & 12 & 6 \\
\hline Kesusilaan & 30 & 95 & 47 & 59 & 71 \\
\hline Pembunuhan & 169 & 217 & 216 & 169 & 116 \\
\hline Penganiayaan & 1 & 51 & 59 & 90 & 129 \\
\hline Pencurian & & 30 & 100 & 114 & 129 \\
\hline Perampokan & & & 3 & 12 & 5 \\
\hline Penggelapan & & 4 & 36 & 14 & \\
\hline Penipuan & & 8 & 12 & 1 & 5 \\
\hline
\end{tabular}

Data di atas menunjukkan bahwa jenis kejahatan dan pelanggaran yang menonjol adalah kesusilaan, pembunuhan, penganiayaan, pencurian. Penganiayaan dan pencurian meningkat.

Pertanyaan: Mengapa jenis-jenis kejahatan dan pelanggaran di atas terjadi di Kabupaten Samosir di mana mayoritas besar penduduknya beragama Kristen dan Katolik? Tidakkah data ini mengatakan bahwa agama kurang atau sama sekali belum berperan dalam kehidupan sosial masyarakat di Kabupaten Samosir? Kenyataan dan pertanyaan ini mau tak mau menyeret kita untuk melihat apa itu agama dan peranannya.

\section{Agama}

Menurut Kamus Besar Bahasa Indonesia (Edisi Ketiga, 2002), agama adalah ajaran atau sistem yang mengatur tata keimanan (kepercayaan) dan peribadatan kepada Tuhan Yang Maha Kuasa serta tata kaidah yang berhubungan dengan pergaulan manusia dan manusia 
serta lingkungannya. Berdasarkan asal-usul kata 'agama' dari kata Latin 'religare' yang berarti menyatukan, Swami Paramananda menulis:

Religion or spirituality is the science and art that teaches man how to get united with the cosmos or with God. It connotes the same meaning as the word yoga. Man is not separate from the cosmos, but due to ignorance and the limitations of his mind, he identifies himself with merely his physical body. This creates the notion of fragmented consciousness or separation from the whole, hence the feeling of 'I, mine and thine.'

Dalam definisi di atas, unsur-unsur agama adalah sistem yang mengatur: keimanan manusia akan Allah, norma-norma antar manusia, dan relasi manusia dengan alam. Ketiga unsur ini mengarah kepada relasi dan kesatuan manusia dengan Allah dan alam semesta.

\section{Peranan Agama: Edukasi Moral}

Menurut hemat saya, peran sentral agama dalam pembangunan Kabupaten Samosir, juga NKRI, adalah edukasi moral. Obervasi dan realita Kabupaten Samosir yang disebut di atas berkaitan erat dengan moral. Karena mayoritas besar penganut agama Kristen dan Katolik di Kabupaten Samosir, maka edukasi moral itu didekati dari sisi kristiani. Di manakah edukasi moral itu terdapat dalam ajaran kristiani? Dalam hukum cinta kasih.

Asal-usul hukum cinta kasih adalah Dekalog atau Sepuluh Perintah Allah. Dekalog berisi deklarasi kehendak Allah perihal bagaimana seharusnya manusia berperilaku kepada Allah dan kepada sesama manusia secara manusiawi.

Berikut disajikan naskah dekalog menurut versi Katolik dan Protestan. Hal ini disajikan bukan untuk menekankan perbedaan, tetapi kesamaan, yakni isinya adalah hukum cinta kasih. 


\begin{tabular}{|c|c|c|c|}
\hline & KATOLIK & PROTESTAN & \\
\hline 1 & $\begin{array}{c}\text { Akulah Tuhan, Allahmu: } \\
\text { Jangan menyembah berhala, } \\
\text { berbaktilah kepadaKu saja, } \\
\text { dan cintailah Aku lebih dari } \\
\text { segala sesuatu. }\end{array}$ & $\begin{array}{c}\text { Jangan punya Allah lain } \\
\text { selain Aku. }\end{array}$ & 1 \\
\hline 2 & $\begin{array}{c}\text { Jangan menyebut Nama } \\
\text { Tuhan Allahmu dengan } \\
\text { tidak hormat. }\end{array}$ & $\begin{array}{c}\text { Jangan membuat patung } \\
\text { yang menyerupai apa yang } \\
\text { di langit atau di bumi atau } \\
\text { di laut. }\end{array}$ & 2 \\
\hline 3 & Kuduskanlah hari Tuhan. & $\begin{array}{l}\text { Jangan menyembah nama } \\
\text { Allah dengan sia-sia. }\end{array}$ & 3 \\
\hline 4 & Hormatilah ibu-bapamu. & $\begin{array}{c}\text { Ingatlah hari Sabat dan } \\
\text { kuduskanlah. }\end{array}$ & 4 \\
\hline 5 & Jangan membunuh. & Hormatilah ayah ibumu. & 5 \\
\hline 6 & Jangan berzinah. & Jangan membunuh. & 6 \\
\hline 7 & Jangan mencuri. & Jangan berbuat cabul. & 7 \\
\hline 8 & $\begin{array}{l}\text { Jangan bersaksi dusta } \\
\text { tentang sesamamu. }\end{array}$ & Jangan mencuri. & 8 \\
\hline 9 & $\begin{array}{l}\text { Jangan mengingini istri } \\
\text { sesamamu. }\end{array}$ & $\begin{array}{c}\text { Jangan bersaksi dusta pada } \\
\text { sesama. }\end{array}$ & 9 \\
\hline 10 & $\begin{array}{l}\text { Jangan mengingini milik } \\
\text { sesamamu secara tidak adil. }\end{array}$ & $\begin{array}{c}\text { Jangan ingin akan istri } \\
\text { sesamamu atau segala } \\
\text { miliknya. }\end{array}$ & 10 \\
\hline
\end{tabular}

Perintah pertama sampai dengan ketiga mengatur kewajiban manusia sebagai umat kristiani kepada Allah dan perintah keempat sampai dengan kesepuluh mengatur kewajiban moral umat kristiani kepada sesama. Dekalog ini diringkas dengan mantap dan sempurna dalam hukum cinta kasih: mencintai Tuhan seutuhnya dan dan mencintai sesama manusia seperti mencintai diri sendiri. Rujukan biblis tentang hal ini terdapat dalam Lukas 10:25-30.

Pada suatu kali berdirilah seorang ahli Taurat untuk mencobai Yesus, katanya: "Guru, apa yang harus kuperbuat untuk memperoleh hidup yang kekal?" Jawab Yesus kepadanya: "Apa yang tertulis dalam hukum Taurat? Apa yang kaubaca di sana?" Jawab orang itu: "Kasihilah Tuhan, Allahmu, dengan segenap hatimu, dan dengan segenap jiwamu dan dengan segenap kekuatanmu dan dengan segenap akal budimu, dan kasihilah sesamamu manusia seperti dirimu sendiri." Kata Yesus kepadanya: 
Gonti Simanullang, Peranan Agama dalam Pembangunan Kabupaten Samosir

"Jawabmu itu benar; perbuatlah demikian, maka engkau akan hidup." Tetapi untuk membenarkan dirinya orang itu berkata kepada Yesus: "Dan siapakah sesamaku manusia?" Jawab Yesus: "Adalah seorang yang turun dari Yerusalem ke Yerikho..."

Sebagaimana diuraikan di atas, tampaknya umat beriman kristiani telah mengamalkan perintah pertama sampai dengan ketiga tetapi melalaikan perintah keempat sampai dengan kesepuluh. Kita tampak saleh dan takwa kepada Tuhan, tetapi kita bisa kalap, kejam, kasar untuk tidak menggunakan kata 'biadab' - terhadap sesama warga. Maka bila kita bisa tampak saleh dan takwa kepada Allah sementara kasar kepada sesama berarti kita amat pintar bertopeng. Saleh dan takwa kepada Allah semestinya menjiwai relasi dan interaksi kita sebagai warga Kabupaten Samosir dan sebaliknya.

Tiga abad sebelum kekristenan moral telah dibicarakan oleh Aristoteles ( $\underline{384}-\underline{322 \mathrm{SM}})$ yang adalah seorang filsuf Yunani, murid Plato dan guru Alexander Agung. Dalam Nichomachian Ethics ia membahas summum bonum, the highest good, kebaikan tertinggi.

Asumsi Aristoteles berbunyi sbb: "Setiap seni, penyelidikan, tindakan dan usaha bertujuan untuk mencapai yang baik". Kita bertindak demi sesuatu. Dan kita bertidak demi sesuatu itu bukan secara mekanis, tetapi secara rasional. Jika tindakan kita tidak dimaksudkan untuk mencapai tujuan atau jika tindakan kita tidak mempunyai tujuan, maka tindakan itu tergolong tindakan acak yang umumnya dilakukan orang yang senewen.

Aristoteles mengatakan bahwa ada tujuan yang dicari demi tujuan lain dan ada tujuan yang dicari demi tujuan itu sendiri. Ia menilai uang dan kuasa sebagai contoh tujuan yang dicari demi tujuan lain. Uang dan kuasa merely useful untuk mencapai tujuan lain. Kegiatan yang sedang kita lakukan ini bukanlah tujuan dalam dirinya sendiri, melainkan untuk tujuan lain.

Menurut Aristoteles, sumum bonum itu adalah eudaimonia (happiness, kebahagiaan). Inilah tujuan yang dicari manusia demi tujuan itu sendiri, bukan demi tujuan lain. Secara umum, eudaimonia dapat diterjemahkan sebagai kombinasi kemakmuran, berkat, keberhasilan, perkembangan, kemajuan, dan self-sufficiency. Inilah situasi di mana orang bertindak dengan baik dan menjadi baik dalam bertindak dengan baik (a state of doing well and being good in doing well). 
Aristoteles berargumen bahwa kesenangan dan kehormatan, kendatipun dikehendaki dalam dirinya sendiri, pada kenyataannya dicari manusia demi mencapai tujuan lain yakni kebahagiaan.

Kunci untuk menemukan kebahagiaan yang khas manusiawi terletak pada pengidentifikasian fungsi-fungsi yang khas manusiawi. Khas manusiawi berarti hanya manusia yang memilikinya. Fungsi yang unik manusiawi, menurut Aristoteles, adalah rasionalitas atau prinsip rasional, daya nalar. Aristoteles menyatakan bahwa fungsi manusia merupakan aktivitas jiwa (hati nurani) yang mengikuti atau menyiratkan rasionalitas. Maka, fungsi seorang manusia yang baik dan mulia menemukan pemenuhan dalam kinerja yang baik dan mulia di mana diaktualkan fungsi rasionalitas itu. Cara terbaik bagi manusia untuk mencapai kebahagiaan, menurut Aristoteles, adalah menggunakan rasionalitas atau akal budinya, dan penggunaanya yang tepat merupakan prasyarat bagi seorang manusia untuk dapat berbuat dengan baik dalam kehidupan. Melalui rasionalitaslah seseorang menyimbang dan memilih apa yang terbaik dalam situasi tertentu, dan melalui akal budi seseorang sampai pada pengetahuan umum tentang apa yang terbaik.

Selanjutnya Aristoteles mengatakan hal berikut: jika fungsi manusia merupakan aktivitas jiwa yang mengikuti prinsip rasional, dan fungsi seorang manusia yang baik adalah mengikuti dengan baik prinsip rasional, lantas apa yang diperlukan seorang untuk melaksanakan prinsip rasional dengan baik? Jawaban Aristoteles adalah keutamaan-keutamaan (virtues) seperti penilaian yang baik dan tepat, kejujuran, moderasi/tahu batas, keberanian, dan persahabatan.

Kekuatan lain yang merupakan bagian dari kodrat manusia, seperti reproduksi, nutrisi pertumbuhan, pencarian kesenangan dan pengelakan rasa sakit, adalah fungsi yang bukan khas manusia. Hewan pun memiliki fungsi itu. Pemenuhan fakultas ini, meskipun bagian kodrat kita, tidaklah unik manusia dan, karenanya, tidak cukup untuk memenuhi kebaikan tertinggi yang unik untuk manusia saja. Dengan demikian, eudaimonia menuntut perilaku hidup seseorang yang sesuai dengan kebajikan di bawah bimbingan akal budi. Singkatnya, baik pelaku dan tindakan yang dibuat pelaku itu memang baik. Maka terhadap pertanyaan "how should we live and how should we behave", jawabannya adalah "by being good and doing good" yang berdasar pada hati nurani dan akal budi. 
Gonti Simanullang, Peranan Agama dalam Pembangunan Kabupaten Samosir

\section{Penutup}

Masalah menyangkut etika dan moral para pemimpin lokal dan nasional bangsa Indonesia telah digodok peserta Kongres Tokoh Agama IV di Jakarta. Salah satu rekomedasi, yang disampaikan Slamet Efendy Yusuf, berbunyi sbb: "Salah satu akar masalah yang menyebabkan krisis bangsa Indonesia adalah moralitas yang kian rusak, terutama di kalangan para pemimpin dari tingkat lokal hingga nasional yang tidak sungkan berbuat tercela. Untuk mengatasinya, perlu dikembangkan budaya malu bagi elite politik yang terbukti melanggar etika dan hukum dengan cara mengundurkan diri dari jabatannya" (Kompas, 8 Desember 2012, hlm. 3).

Pernyataan ini mengandung implikasi bahwa hati nurani dan akal budi yang adalah khas manusia telah merosot sehingga bonum commune dikorbankan. Dalam realitas seperti ini Daniel O'Connell, pemimpin politis Irlandia, mengingatkan kita dengan berkata, "Nothing is politically right which is morally wrong". Lantas, Marcus Cato, warga Romawi, berseru, "I prefer to do right and get no thanks rather than to do wrong and get no punishment." Aristoteles memberi dasar etis-normatif kepada kita, O'Connell mengingatkan kita, dan Cato mengajak kita dan Yesus memerintahkan kita umat Kristiani untuk melakukan hukum cinta kasih. Tujuannya satu yakni agar kita semakin mengedepankan perilaku etis-moral dalam kehidupan kita sebagai warga Kabupaten Samosir di mana Kabupaten Samosir kita impikan menjadi Negri Indah, Kepingan Surga. 


\section{DAFTAR PUSTAKA}

Bertens, Kees. Etika. Jakarta: Gramedia Pustaka Utama, 2000.

Darmaputera, Eka, Etika Sederhana untuk Semua: Perkenalan Pertama. Jakarta: BPK Gunung Mulia, 1987.

Magnis-Suseno, Frans. Filsafat sebagai Ilmu Kritis. Yogyakarta: Kanisius, 1992.

Singer, Peter (ed.). A Companion to Ethics. Cambridge, Massachusets: Blackwell Publisher Inc., 1996.

Walsh, George, The Role of Religion in History. New Brunswick, NJ: Transaction Publisher, 1998. 